4. W. Löscher and D. Schwartz-Porsche, J. Neurochem. 46. 1322 (1986).

5. W. Löscher and W. S. Schwark, Brain Res. 339, 146 (1985).

6. K. G. Lloyd, C. Munari, L. Bossi. C. Stoeffels, J. Talairach and P. L. Morselli, in Neurotransmitters, Seizures, and Epilepsy (Eds. P. L. Morselli, K. G. Lloyd, W. Löscher, B. Meldrum and E. H. Reynolds), pp. 325-334. Raven Press, New York (1981).

7. W. Löscher and H. Siemes, Epilepsia 26, 314 (1985).

8. J. H. Wood, T. A. Hare, B. S. Glaeser, J. C. Ballenger and R. M. Post, Neurology 29, 1203 (1979).

9. W. Löscher, in Neurotransmitters, Seizures, and Epilepsy (Eds. P. L. Morselli, K. G. Lloyd, W. Löscher, B. Meldrum and E. H. Reynolds), pp. 93102. Raven Press, New York (1981).

10. M. G. Palfreyman, P. J. Schechter, W. R. Buckett, G. P. Tell and J. Koch-Weser, Biochem. Pharmac. 30, 817 (1981).

11. M. Abe, J. Nutr. Sci. Vitaminol. 24, 419 (1978).

12. W. Löscher, J. Neurochem. 36, 1521 (1981).

13. W. Löscher, M. Vetter, F. Müller, G. Böhme and G. Stoltenburg-Didinger, Neurochem. Int. 6, 441 (1984).

14. S. Sarhan and N. Seiler, J. Neurosci. Res. 4, 399 (1979).

15. J. D. Wood, E. Kurylo and J. D. Newstead, Can. J. Biochem. 56, 667 (1978).

16. J. D. Wood, M. P. Russell and E. Kurylo, J. Neurochem. 35, 125 (1980)

17. M. J. Iadarola and K. Gale, Molec. Cell. Biochem. 39, 305 (1981).

18. W. Löscher and M. Vetter, Biochem. Pharmac. 34, 1747 (1985).
19. M. Abe and M. Matsuda, Neurochem. Res. 8, 563 (1983).

20. W. Löscher, W., Naunyn-Schmiedeberg's Archs Pharmac. 315, 119 (1980).

21. A. Karlson, F. Fonnum, D. Malthe-Sørenssen and J. Storm-Mathisen, Biochem. Pharmac. 23, 3035 (1974).

22. W. Löscher, Biochem. Pharmac. 28, 1397 (1979).

23. W. Löscher, G. Böhme, F. Müller and S. Pagliusi, J. Neurochem. 45, 879 (1985).

24. G. Rodriguez de Lores Arnaiz, M. Alberici di Canal and E. De Robertis, J. Neurochem. 19, 1379 (1972).

25. G. Rodriguez de Lores Arnaiz, M. Alberici di Canal, M. Robiolo and M. Mistrorigo De Pacheco, J. Neurochem. 21, 615 (1973).

26. C. F. Baxter, in Methods of Neurochemistry, Vol. 3 (Ed. R. Fried), pp. 1-73. Marcel Dekker, New York (1972).

27. W. Löscher, J. Neurochem. 32, 1587 (1979).

28. O. H. Lowry, N. J. Rosebrough, A. L. Farr and R. J. Randall, J. biol. Chem. 193, 265 (1951).

29. M. A. Markwell, S. M. Haas, L. L. Bieber and N. E. Tolbert, Analyt. Biochem. 87, 206 (1978).

30. E. J. Hammond and B. J. Wilder, Gen. Pharmac. 16, 441 (1985).

31. R. Tapia, H. Pasantes, M. P. de la Mora, B. G. Ortega and G. H. Massieu, Biochem. Pharmac. 16, 483 (1967).

32. J. D. Wood and S. J. Peesker, J. Neurochem. 20, 379 (1973).

33. G. Bartholini, Med. Res. Rev. 5, 55 (1985).

34. W. Löscher, Drugs Fut. 11, 39 (1986).

\title{
Effect of dietary ascorbate on covalent binding of benzene to bone marrow and hepatic tissue in vivo*
}

(Received 29 October 1985; accepted 14 February 1986)

Benzene produces aplastic anemia in humans and is a human leukemogen $[1,2]$. The biochemical mechanics whereby benzene produces these effects are presently unknown. However, several reports have demonstrated a relationship between covalent binding in the bone marrow, the target site, and benzene-induced blood dyscrasia in laboratory animals $[3,4]$. Toxicity appears to be the result of the metabolic activation of benzene $[5,6]$. Ascorbate has been shown to be effective in preventing the in vitro covalent binding of the metabolites of benzene and phenol, the major metabolite of benzene [7-9]. We have demonstrated previously that, when phenol and hydrogen peroxide are incubated with bone marrow preparations isolated from guinea pigs with low ascorbate tissue concentration, there is a 4 -fold increase in in vitro covalent binding of phenol equivalents to bone marrow tissue when compared to guinea pigs on a high ascorbate intake [9]. Ascorbate cannot be synthesized in the guinea pig or human and must be procured through dietary intake, and the concentrations of ascorbate in tissue can vary widely from individual to individual due to their respective dietary intake [10]. In the present communication, we have investigated the effect of ascorbate on covalent binding of $\left[{ }^{14} \mathrm{C}\right]$ benzene metabolites in vivo. To evaluate the effect of ascorbate on covalent binding in vivo, guinea pigs were placed on different dietary intakes of ascorbate followed by i.p. administration of $\left[{ }^{14} \mathrm{C}\right]$ benzene.

* This work was supported in part by Grant 23007 from Hoffmann-La Roche, Nutley, NJ.
Covalent binding was inversely related to dietary ascorbate intake and to the concentration of ascorbate in both liver and bone marrow. Covalent binding was altered by 2 and 1.4-fold in the liver and bone marrow respectively. The concentration of ascorbate in bone marrow and hepatic tissue ranged from 0.12 to $2.63 \mu$ moles $/ g$ tissue depending upon the dietary intake.

Three groups of four male Hartley guinea pigs (200$250 \mathrm{~g}$ ) were placed on the following dietary intakes of ascorbate: $2.0,0.35$ and $0.05 \mathrm{mg}$ ascorbate $/ \mathrm{ml}$ drinking water for 4 weeks prior to the i.p. administration of benzene. All guinea pigs received ascorbate-deficient guinea pig chow ad lib. (ICN Nutritional Biochemicals, Cleveland, $\mathrm{OH})$. The growth rate for each group of guinea pigs was not significantly different. The guinea pigs on the lowest intake showed no signs of a scorbutic condition. After 4 weeks on the diets, each guinea pig was injected with $660 \mathrm{mg} / \mathrm{kg}\left[{ }^{14} \mathrm{C}\right]$ benzene intraperitoneally twice, 12 and $6 \mathrm{hr}$ before termination. The specific activity of $\left[{ }^{14} \mathrm{C}\right]$ benzene was either 52.7 or $15.2 \mu \mathrm{Ci} / \mu \mathrm{ol} .\left[{ }^{14} \mathrm{C}\right]$ Benzene was injected in $0.5 \mathrm{ml}$ corn oil. Six hours after the second injection the guinea pigs were terminated by decapitation. Each liver was removed, and a $20 \%$ homogenate was made with $100 \mathrm{mM}$ sodium phosphate buffer, pH 7.4. Femurs were removed from each guinea pig, and the bone marrow was scraped out of the femoral cavity. Each marrow sample was weighed and a $10 \%$ homogenate was prepared. Hepatic homogenate $(250 \mu \mathrm{l})$ and bone marrow homogenate $(1.2 \mathrm{ml})$ were extracted, and the covalently bound benzene equivalents in these tissues were determined by the method 
of Tunek et al. [11]. Bone marrow and hepatic ascorbate concentrations were measured in these guinea pigs by the method of Zannoni et al. [12].

The concentrations of ascorbate in bone marrow and liver of the benzene-treated guinea pigs are shown in Table 1. There was approximately a 10 -fold difference in the ascorbate tissue concentration in both liver and bone marrow when the low dietary intake of ascorbate was compared to the high. As shown in Fig. 1, covalent binding of benzene metabolites to hepatic tissue was decreased as the hepatic ascorbate tissue concentration was increased. Covalent binding to hepatic tissue was decreased in the order of 2 fold when the hepatic ascorbate tissue concentration was increased approximately 10 -fold. Covalent binding of benzene equivalents to bone marrow tissue also varied inversely with ascorbate tissue concentration (Fig. 2). Bone marrow ascorbate tissue concentration could also be modulated over 10-fold, while covalent binding could be decreased 1.4-fold.

In the present communication we have demonstrated that ascorbate is capable of altering the covalent binding of benzene metabolites to hepatic or bone marrow tissue in vivo. Covalent binding was inversely related to ascorbate intake and to the concentration of ascorbate in these tissues. The difference in covalent binding between groups may be important with regard to the myelotoxicity of benzene since several investigators have shown that a decrease in covalent binding to bone marrow tissue results in the decreased toxicity of benzene $[3,4]$.

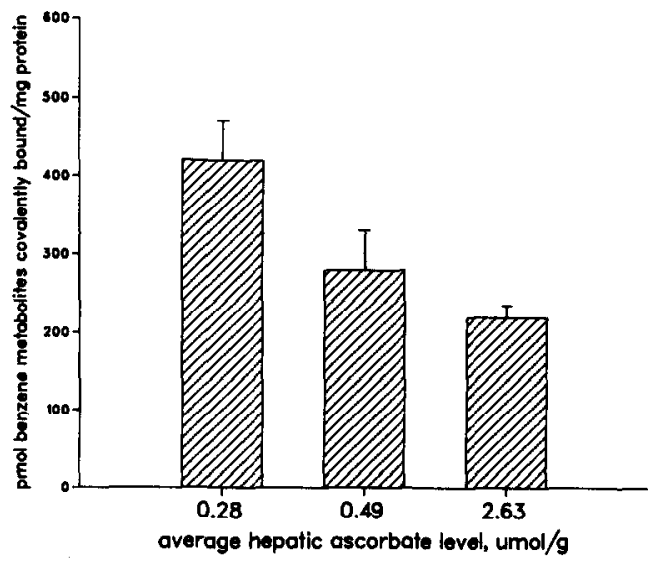

Fig. 1. Covalent binding of the metabolites of benzene in the liver after i.p. administration of $\left[{ }^{14} \mathrm{Clbenzene}\right.$. $\left[{ }^{14} \mathrm{C}\right]$ Benzene $(660 \mathrm{mg} / \mathrm{kg})$ was administered 12 and $6 \mathrm{hr}$ before termination to three groups of guinea pigs on different dietary intakes of ascorbate. Ascorbate and binding values were determined for each guinea pig, and the values are expressed as the mean \pm standard deviation. $\mathrm{P}<0.01$ with respect to $0.28 \mu \mathrm{mole} / \mathrm{g}$ ascorbate to 2.63 .
The differences in covalent binding are small when compared to the differences in the concentration of ascorbate in these tissues. We have demonstrated previously that ascorbate via its antioxidant activity is capable of inhibiting the in vitro covalent binding of the metabolites of phenol by over $90 \%$ and, when benzene is employed as the substrate, covalent binding is inhibited by $35 \%$ and this changes only slightly when the concentration of ascorbate is increased from 1 to $5 \mathrm{mM}$ [9]. Similarly, in the present study the in vivo covalent binding of benzene equivalents after i.p. administration of benzene was decreased $30 \%$, while the bone marrow ascorbate concentration was altered 10 -fold. These data may suggest that the reactive species responsible for the observed covalent binding is only slightly refractory or non-refractory to the antioxidant effect of ascorbic acid. This is in keeping with the concept that the major species responsible for the observed in vivo covalent binding may not be the oxidized forms (hydroquinone, catechol or phenol) since we have demonstrated previously that ascorbic acid is very effective in reducing these metabolites and thus preventing their interaction with tissue macromolecules $[8,9]$. Another possible explanation to consider is that the cellular distribution of ascorbate is such that it is not at a substantial concentration at the site of reactive metabolite formation. Nevertheless, the dietary intake of ascorbate does alter the covalent binding of benzene metabolites to both bone marrow and hepatic tissue in vivo, and this event in the bone marrow is associated with the myelotoxicity of benzene $[3,4]$.

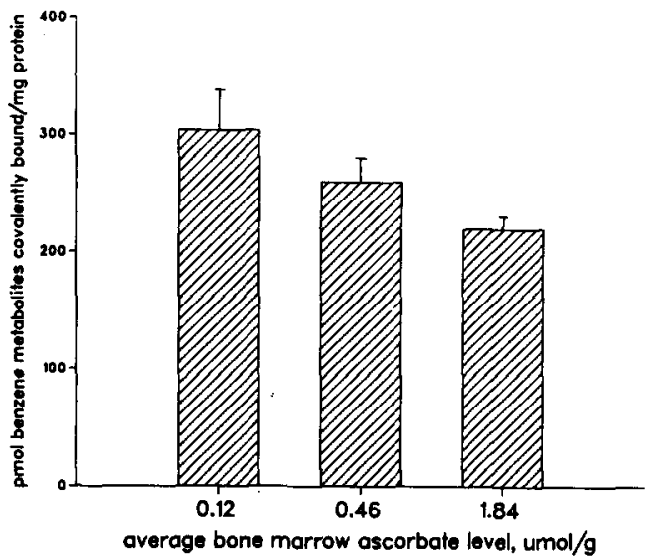

Fig. 2. Covalent binding of the metabolites of benzene in the bone marrow after i.p. administration of $\left[{ }^{14} \mathrm{C}\right]$ benzene. $\left[{ }^{14} \mathrm{C}\right]$ Benzene $(660 \mathrm{mg} / \mathrm{kg})$ was administered 12 and $6 \mathrm{hr}$ before termination to three groups of guinea pigs on different dietary intakes of ascorbate. Ascorbate and binding values were determined for each guinea pig and the values are expressed as the mean \pm standard deviation. $P<0.01$ with respect to $0.12 \mu$ mole $/ \mathrm{g}$ ascorbate to 1.84 .

Table 1. Ascorbate concentration in liver and bone marrow of guinea pigs on the three dietary regimens of ascorbate

\begin{tabular}{|c|c|c|}
\hline \multirow[b]{2}{*}{ Dietary regimens } & \multicolumn{2}{|c|}{$\begin{array}{l}\text { Ascorbate tissue concentration } \\
\qquad(\mu \text { moles } / \mathrm{g})\end{array}$} \\
\hline & Liver & Bone marrow \\
\hline $2.0 \mathrm{mg}$ Ascorbate $/ \mathrm{ml}$ drinking water & $2.63 \pm 0.49$ & $1.84 \pm 0.24$ \\
\hline $0.35 \mathrm{mg}$ Ascorbate $/ \mathrm{ml}$ drinking water & $0.43 \pm 0.11$ & $0.46 \pm 0.17$ \\
\hline $0.05 \mathrm{mg}$ Ascorbate $/ \mathrm{ml}$ drinking water & $0.28 \pm 0.06$ & $0.12 \pm 0.02$ \\
\hline
\end{tabular}

Values are expressed as the mean \pm standard deviation of four guinea pigs/dietary intake. 
Department of Pharmacology and ROBERT C. SMART* Department of Environmental VINCENT G. ZANNONI $\dagger$ and Industrial Health

Toxicology Program

The University of Michigan

Ann Arbor, MI 48109, U.S.A

\section{REFERENCES}

1. R. Snyder and J. J. Kocsis, CRC Crit. Rev. Toxic. 3, 265 (1975).

2. International Agency for Research on Cancer, Monographs on the Evaluation of Carcinogenic Risk of Chemicals to Man: Some Industrial Chemicals and Dyestuffs, pp. 93-148 and 395-8. International Agency for Research on Cancer, Lyon (1982).

* Present address: Laboratory of Experimental Carcinogenesis and metabolism, Building 86, Room 816, Roche Institute of Molecular Biology, Nultey, NJ 07110.

$\uparrow$ All correspondence should be addressed to: Vincent G. Zannoni, Ph.D., Department of Pharmacology, M6322 Medical Science I, University of Michigan Medical School, Ann Arbor, MI 48109-0010.
3. S. L. Longacre, J. J. Kocsis and R. Snyder, Toxic. appl. Pharmac. 60, 398 (1981).

4. R. D. Irons, W. F. Greenlee, D. Wierda and J. D. Bus, in Biological Reactive Intermediates (Eds. R. Snyder, D. Parke, J. Kocsis, D. Jollow, C. G. Gibson and C. Witmer), Vol. 136, pp. 229-43, in the series Advances in Experimental Medicine and Biology. Plenum Press, New York (1982).

5. D. Sammett, E. W. Lee, J. J. Kocsis and R. Snyder, J. Toxic. Environ. Hlth 5, 785 (1979).

6. L. S. Andrews, E. W. Lee, C. M. Witmer, J. J. Kocsis and R. Snyder, Biochem. Pharmac. 26, 293 (1977).

7. T. Sawahata and R. A. Neal, Molec. Pharmac. 23, 453 (1983).

8. R. C. Smart and V. G. Zannoni, Molec. Pharmac. 26, 105 (1984).

9. R. C. Smart and V. G. Zannoni, Toxic. appl. Pharmac. 77, 334 (1985).

10. H. E. Sauberlich, Ann. N.Y. Acad. Sci. 258, 438 (1975).

11. A. Tunek, K. L. Platt, P. Bentley and F. Oesch, Molec. Pharmac. 14, 920 (1978).

12. V. Zannoni, M. Lynch, S. Goldstein and P. Sato, Biochem. Med. 11, 41 (1974).

\section{Endocytosis of proteins by kidney tubule cells: inhibition by the aminoglycoside gentamicin}

Nephrotoxicity is a major limitation to the long term use of aminoglycoside antibiotics such as gentamicin. This nephrotoxicity is associated with damage to both kidney glomerulus and tubule and is dependent on such factors as dose, duration of exposure, age and sex [1]. Early renal dysfunction has been related to the accumulation of aminoglycosides in the lysosomes of proximal tubule cells $[2,3]$. Gentamicin also accumulates in lysosomes of other cell types such as fibroblasts [4] as has been shown for other weak bases [5].

Proximal tubule cells in the kidney are responsible for the reabsorption and degradation of protein remaining after ultrafiltration in the glomerulus [6]. It has been suggested [7] that an initial event in normal tubular protein reabsorption is an interaction between the protein and an anionic binding site at the proximal tubule brush border. Additionally, competition for such sites by polycationic aminoglycosides appears to take place [8]. Thus the effect of gentamicin on the renal handling of proteins is of interest.

We have recently used a kidney cell line--Madin Darby Canine Kidney (MDCK) cells-to study the selectivity in adsorptive endocytosis of different size proteins by tubular cells [9]. The present study utilises this cell line to investigate the effects of gentamicin on the uptake and degradation of ral plasma proteins.

\section{Materials and methods}

MDCK cells were maintained in monolayer culture in Eagles minimum essential medium (MEM) (Flow Laboratories) supplemented with $10 \%$ heat inactivated foetal calf serum and antibiotics. Rat serum (Miles Laboratories, Bucks, U.K.) was inactivated by heating at $56^{\circ}$ for $30 \mathrm{~min}$ and then separated into three molecular size fractions by gel filtration on a Sepharose 6B column (Pharmacia, Sweden). Gel electrophoresis on $7.5 \%$ non-denaturing gel in Tris-glycine $\mathrm{pH} 8.9$ showed the largest molecular size fraction to contain predominantly macroglobulins. The intermediate size fraction comprised gammaglobulins with some albumin and the smallest molecular size fraction contained albumin and the smaller proteins. Aliquots of concentrated fractions were iodinated using the iodogen method $[10]$ and the reaction products dialysed against phosphate buffered saline (PBS) after which less than $2 \%$ of the radioactivity was soluble in $5 \%$ trichloroacetic acid (TCA). Competition studies (data not show) indicated that the iodinated protein was recognised in a similar manner to the unlabelled protein as would be expected with the mild iodination procedure employed. All reagents were of the best available commercial grade.

MDCK cells were seeded at low density and allowed to grow to confluence over a period of 5 days in the presence of gentamicin (Flow Laboratories) in the concentration range $250-1000 \mu \mathrm{g} / \mathrm{ml}$ of culture medium. For the measurement of endocytosis, $\left[{ }^{3} \mathrm{H}\right]$-sucrose (Amersham International) or ${ }^{125}$ I-labelled proteins were then presented to the resultant confluent cell monolayers in fresh serum supplemented culture medium containing gentamicin such that gentamicin was present throughout the experimental period at the same concentrations as used in the preincubations. At the commencement of uptake the confluent monolayer consisted of viable cells and viability was maintained throughout the experiments as judged by morphology and retention of cell protein in the monolayer.

In order to measure uptake and degradation at chosen times after addition of the substrate, the media were harvested and the cells washed four times with ice-cold PBS to remove extracellular radioactivity. The cells were then lysed by the addition of $0.1 \%$ Triton X-100 in PBS. To measure uptake and degradation, media and cell fractions were precipitated with 5\% TCA and TCA soluble and insoluble fractions counted separately by a gamma counter (Ultragamma $1280, \mathrm{LKB}$ ) or, for $\left[{ }^{3} \mathrm{H}\right]$-sucrose uptake, aliquots counted directly in a liquid scintillation counter (Packard Tricarb 460C). An aliquot of each cell sample was assayed for protein by the method of Lowry et al. [11] using bovine serum albumin as standard. Uptake was 